Commentary

\title{
Division of Labour, Work-Life Conflict and Family Policy: Conclusions and Reflections
}

\author{
Michael Ochsner ${ }^{1, *}$, Ivett Szalma ${ }^{2,3}$ and Judit Takács ${ }^{2,4}$ \\ ${ }^{1}$ FORS - Swiss Centre of Expertise in the Social Sciences, University of Lausanne, 1015 Lausanne, Switzerland; \\ E-Mail: michael.ochsner@fors.unil.ch \\ ${ }^{2}$ Centre for Social Sciences, Hungarian Academy of Sciences Centre of Excellence, 1097 Budapest, Hungary; \\ E-Mails: szalma.ivett@tk.mta.hu (I.S.), takacs.judit@ tk.mta.hu (J.T.) \\ ${ }^{3}$ Corvinus University of Budapest, 1093 Budapest, Hungary \\ ${ }^{4}$ KWI Essen-Kulturwissenschaftliches Institut, 45128 Essen, Germany \\ * Corresponding author
}

Submitted: 1 September 2020 | Published: 9 October 2020

\begin{abstract}
This thematic issue aims to shed light on different facets of the relationship between division of labour within families and couples, work-life conflict and family policy. In this afterword, we provide a summary of the contributions by emphasizing three main aspects in need of further scrutiny: the conceptualisation of labour division within families and couples, the multilevel structure of relationships and the interactions of gender(ed) values at different levels of exploration.
\end{abstract}

\section{Keywords}

division of labour; care work; family policy; gender equality; long-term care; non-paid work; work-family conflict; work-life balance; work-life conflict

\section{Issue}

This commentary is part of the issue "Division of Labour within Families, Work-Life Conflict and Family Policy" edited by Michael Ochsner (FORS Lausanne, Switzerland), Ivett Szalma (Centre for Social Sciences, Hungarian Academy of Sciences Centre of Excellence, Hungary/Corvinus University of Budapest, Hungary) and Judit Takács (Centre for Social Sciences, Hungarian Academy of Sciences Centre of Excellence, Hungary/KWI Essen, Germany).

(C) 2020 by the authors; licensee Cogitatio (Lisbon, Portugal). This article is licensed under a Creative Commons Attribution 4.0 International License (CC BY).

\section{Introduction}

The contributions in this thematic issue show that the relationship between division of labour within couples, work-life conflict and family policy is highly complex by revealing relevant insights on a number of aspects of this relationship. While there is ample research on country differences in family policy, on work-life conflict (and it's different conceptual colours as work-family conflict, work-family conflict, work-life balance, etc.) and on labour division within families and couples, less is known on the relationship between the three, especially when it comes to gender differences. Yet, it is the (gendered) relationship between those three concepts that needs scien- tific as well as policy attention because an isolated view on just one or two of them might miss the connection to real-life and bias the perspective because the three are inseparable.

In this concluding commentary, we summarise the findings of the contributions, pointing to three main aspects of the relationship between labour division within families and couples, work-life conflict and family policy. We then briefly demonstrate the complexity of the endeavour of comparative research regarding this relationship and point out theoretical and methodological lacunae. We conclude by pointing out the main findings of this thematic issue and their policy implication. 


\section{Three Aspects in Need of Scrutiny}

Summarising the contributions of this thematic issue, we want to point out a few aspects that need more attention in the current scientific and policy discourse: First, labour division needs a broader conceptualisation including care work, also outside the family. Second, the relationships between labour division, work-life conflict and family policy take place in a multilevel context: The individual-level (household, class, values), meso-level (economy: employment, work demands) and macrolevel (region, country: policy and culture) influence how partners share their work and how this has repercussions on work-life conflicts. We think that the meso-level and its interaction with the other levels is particularly under-researched. Third, values regarding gender roles and family arrangements as well as attitudes towards gender inequalities need to be taken into account on all the three levels including how such values are shaped by the three levels.

\subsection{Conceptualisation of Labour Division within Families and Couples}

As already pointed out in the introduction to this thematic issue, there is a lack of precision in the definition of labour division within families and couples. The plethora of definitions can be classified on a scale from very inclusive where all non-paid work within or outside the household is included blurring the limits between voluntary and housework (e.g., OECD, 2011, p. 10) to a very limited perception of non-paid work as female-attributed housework like dishwashing and cleaning (e.g., Hu \& Yucel, 2018; Ruppanner, Bernhardt, \& Brandén, 2017). However, the contributions in this thematic issue show that it does matter what is included in the definition of non-paid work and that non-paid work indeed encompasses different tasks. Bornatici and Heers (2020) demonstrate how important care work is regarding work-life conflict: When analysing family arrangement according to time spent on all tasks (paid, non-paid and care work), equal arrangements are associated with lower work-life conflict. However, when differentiating between paid, domestic and care work, equally sharing care work lowers work-life conflict while equally sharing paid or domestic work does not. Thus, researchers would draw the wrong conclusion that equally sharing tasks is linked to less work-life conflict when in fact, sharing care work is the main driver. Aidukaite and TelisauskaiteCekanavice (2020) reveal that policy can change how care for children is shared within a family: While the Swedish model with non-transferable father's leave leads to a norm that fathers take a more important role in child care, Lithuanian policy focusing on financial security where fathers can even work during their parental leave and grandparents can take parental leave to take over care duties, fathers involve much less in child care. Moreover, long-term care policies differ across countries as Bartha and Zentai (2020) demonstrate. The study on long-time care also puts forward that not only childcare is a relevant factor in labour division within families but also care for elderly and disabled. Importantly, paid and non-paid care work is mostly done by women and is embedded in hierarchies reflecting power relations between employers and employees, citizens and migrants as well as men and women. Paid care allows (mainly) women to engage in paid work and do less housework. At the same time, paid care creates opportunities to gain an independent revenue in care jobs (again mostly taken by women). However, an achievement of more equal share of care-duties within a family comes with a grain of salt when considering the broader context. In countries where women participate more equally in paid work, care work is not only shared more equally within couples but also more likely to be outsourced to paid care. This can lead to gendered job situations in which women take less-paid jobs in the care sector or the care work is externalised to migrants where women from other, poorer countries take over care work. Due to lack of macro-data on the share of migrants in paid care, the authors could not take this factor into account in their model but suggest digging deeper into the potential issue of a new gendering of care through migration, or "global care chain" (see also Estéves-Abe \& Hobson, 2015). Theoretical work, however, suggests complex relationships because of the involvement of so-called global families: Migrant women are not only exploited or climb the ladder when exploiting other women (Lutz, 2002), they might do lowpaid jobs in Europe but might gain power and independency vis-à-vis their partners and families in their home country (Beck \& Beck-Gernsheim, 2011). Such issues need certainly more theoretical and empirical development. The COVID-19 pandemic has shown, however, that those women (together with informal [male] farming and restaurant helpers) are the first to be in a very difficult situation in such a crisis, as the long waiting line for food parcels in Geneva showed, bringing the informal sector in one of the world's richest cities out of the shadow (Kingsley, 2020).

\subsection{Multilevel Structure of Relationships}

Second, decisions are taken in a multilevel context. While the individual level and the country level are well-researched (however, not always with consistent results; see Masuda, Sortheix, Beham, \& Naidoo, 2019; Ruppanner, 2011), the meso-level, i.e., the situation at the workplace and labour market, is less researched (with the exception of working conditions, e.g., Gallie \& Russell, 2009). Kromydas (2020) shows that education, in its mediating role between the individual and the meso level, plays a complex role regarding the relationship between division of labour and work-life conflict. Higher education can lead to higher work-life conflict for women, probably because they do double-shifts taking the same household duties but having more de- 
manding jobs. On the other hand, higher education can work as a cushion for women in times of crisis. Women are more affected by economic crises than men everything held equal, but education reduces this negative effect. Demand of work force seems to play a role here as higher educated women seem to have more crisis resistant jobs than lower educated women. In other words, among highly educated, the difference between men and women regarding crisis resistant jobs is smaller than among low educated. Similarly, Ukhova (2020) finds for the Central and Eastern European countries that in the higher social class, gender equality has progressed while in the lower social class it has regressed.

A series of contributions in this thematic issue put forward that preferences in labour division do not always match with practice (Bornatici \& Heers, 2020; Geszler, 2020; Nagy, 2020; Zimmermann \& LeGoff, 2020). This is attributed to restrictions imposed by the work place, be it the difficulty for men to reduce their work percentages, availability of technical tools to increase flexibility to be productive during care time or the persistence of the "ideal employee" norm (Geszler, 2020; Nagy, 2020; Zimmermann \& LeGoff, 2020). There is also an interaction between the meso and the macro level in the sense that policy can shape values in companies and the economic and political situation can turn countries into victims of globalisation when employers can put pressure on employees to be ever more committed to work, which can lead to stronger corporate "colonisation" where employees can be always reached and work time expands into private time due to technology (Geszler, 2020; Nagy, 2020; Ukhova, 2020).

\subsection{Gender Values and the Interactions of Gender Values at Different Levels}

Third, gender values need to be taken into account, not only on a macro level but also on the individual and organisational level (Bornatici \& Heers, 2020; Ukhova, 2020; Zimmermann \& LeGoff, 2020). Gender values relate to how people see the roles of the genders, what constitutes a family and how it is organised, how an optimal labour division within families is seen, etc. Such values can shape policies (as voters choose representatives sharing their sets of values) and policies can shape values (by emphasising certain role models over others; see the case of Sweden's "daddy leave" in Aidukaite \& Telisauskaite-Cekanavice, 2020). In any case, couples do not take their decisions on division of labour in a void but in a multilevel environment, where each level can have value preferences. On the micro or individual level, some couples prefer egalitarian arrangements whereas other couples prefer a traditional family organisation. On the meso or economic level, employers and the labour market can facilitate some arrangements or make them impossible to realise (Geszler, 2020; Zimmermann \& LeGoff, 2020). Moreover, preferences differ also on the macro or country level and policy can facilitate more or less egalitarian models (e.g., policy can grant long maternity leaves but no parental or paternity leave). To make things more complex, the choice of family arrangement on the individual level can be mediated by social class as Ukhova (2020) shows or regional culture as Zimmermann and LeGoff (2020) point out. Such interactions between the different levels matter regarding how the family arrangement affects work-life conflict as Bornatici and Heers (2020) demonstrate: Couples having a consistent modern traditional arrangement in an egalitarian society experience higher work-life conflicts while couples having a consistent egalitarian arrangement in an egalitarian society experience the least work-life conflict.

\section{Issues for Future Research on Labour Division, Work-life Conflict and Family Policy}

The focus on only these three aspects shows that the relationships are complex-much more complex than the current state of theory and operationalisation can capture. Consequently, there is a need for theoretical and conceptual development as well as on empirical and methodological refinement. On the one hand, the conceptual definitions of labour division within families and couples need scrutiny: Certainly, care tasks need to be included and the different levels of care examined. Furthermore, we need more explicit theories about the relationships between labour division, work-life conflict and family policy: How do they interact on the different levels on which they are active (individual, economic and country)? What are the consequences of achieving a more equal share of paid and non-paid work in couples? Does this come with gendered work patterns or even relocation of the gender divide to other world regions? Does the latter rather put migrant women into dependencies or empower them to be more independent (Beck \& Beck-Gernsheim, 2011; Lutz, 2002)? Does technology facilitate a reconciliation between family and career or rather simply increase corporate colonization (Nagy, 2020)? Can technology help involve men more in family matters or is it rather used to increase female labour participation while keeping them doing the care work?

Finally, we want to point out a methodological issue we have encountered in the production of this thematic issue linked to the complex multilevel structure of the relationships examined: Hierarchical linear multilevel models are the methodological mainstream when researchers tackle concepts affecting different levels (e.g., Masuda et al., 2019; Ruppanner, 2011). They mostly rely on maximum likelihood and assume equal effects (and variances) on the individual level across countries. However, when it comes to policy, we cannot assume equal fixed effects and variances across countries anymore (Achen, 2005) and when studying policy, we are usually interested in country-level effects for which maximum likelihood provides poor precision (Bowers \& Drake, 2005). Therefore, it is not surprising that results from 
such studies are inconclusive or show unexpected results (as noticed by Masuda et al., 2019). To address this issue, two-step procedures could be employed that take into account that effects on the individual level vary across countries (Achen, 2005; Bowers \& Drake, 2005; Bryan \& Jenkins, 2016), for example because of different family policies impacting the relationship between division of labour and work-life conflict. However, such methods seem to be ignored by most scholars in the field and false beliefs about multilevel models are prevalent, for example, if data have a multilevel structure, multilevel modelling must be applied, as the work on this thematic issue showed. None of the articles submitted used multilevel modelling for the obvious reasons, however, the reviewers still asked all authors to apply multilevel modelling. One reason for the dislike of two-step methods is that the results and study description might look more complicated than the multilevel model. To improve the presentation of such models and their acceptance in the field, we need some methodological and theoretical work to be done: Such varying relationships across countries are complex and theories for how such differences could look like are missing, making it very difficult to come to easily presentable results within the limits of a journal article.

We therefore want to put forward that rather than just applying the mainstream method to all research, researchers must reflect on their research question and choose the appropriate method. We illustrate this point using a small example.

\subsection{Example of the Difference between Multilevel Models and Two-Step Procedures}

Our previous research inciting the idea of this thematic issue at a conference aimed at investigating whether a new vulnerable group regarding work-life conflict emerged in the context of the economic crisis of 2007 and, using data from the European Social Survey (ESS) rounds 4 and 8 , found that not only the unemployed fall into difficult situations, but also some working parents can be seen as a vulnerable group as work demands increase and family demands do not decrease (Ochsner \& Szalma, 2017). For this research, we applied the conventional multilevel model approach as we were investigating whether, across Europe, a new vulnerable group emerges. We were thus seeking a general trend in European countries; moreover, our interest did not lie in the size of country level predictors. If, however, we would aim at identifying whether policies can alleviate worklife conflict and whether we find differences across family policy regimes, we were not interested in a general pattern at the individual level valid for all countries but in the differences across countries in how work-life conflict comes about. In such a case, the preferred approach would be a two-step procedure, in which an OLS regression for each country was calculated in the first step and in the second step patterns in the coefficients were iden- tified. Applying such a model as an example to demonstrate the methodological issue, we find that, using the same data, the ESS 2010 (ESS, 2012), and the same country selection, the independent variables' effects did indeed differ considerably across countries. Without going into detail or trying to interpret results, which would demand additional efforts for which we do not have the space, the example shows clearly that the effects at the individual level vary considerably across countries. Therefore, as soon as one wishes to investigate country differences or policy effects, fixed-effects or multilevel models are inadequate as they blur exactly what one wants to investigate (for a schematic presentation of effect sizes, see Figure 1, for the full table and a description of the variables used, see supplemental material).

However, interpreting such results is quite demanding as patterns are not necessarily straight forward. First and foremost, we do not have enough detailed theoretical knowledge about how policy shapes family arrangements and employers' decisions and their effect on work-life conflict to formulate clear hypotheses to test. Second, there is still only little methodological guidance on how to explore relationships on the second level without running endless numbers of regressions or generating visualisations on each coefficient and bringing them back into a full picture. If we want to take our understanding of the division of labour within families and couples to the next level, theoretical and methodological efforts must be made to link family policy with division of labour and work-life conflict and their interactions on the different levels as the relationships do not follow a linear pattern in the sense that generous family policy would lead to less work-life conflict and a more egalitarian division of labour (see also Crompton \& Lyonette, 2006; Strandh \& Nordenmark, 2006).

\section{Conclusions and Policy Recommendations}

This thematic issue puts forward a few points relevant for research and policy with regard to labour division within families and couples and work-life conflict. We identified three aspects that need scrutiny: First, labour division needs to be conceptualised more broadly and include care work; second, the multilevel structure needs to be taken into account, especially at the meso-level the economy, the labour market and employers as well as the restrictions they impose on decision making in couples; third, values regarding labour division differ and need to be taken into account at each level.

A perspective taking these three aspects into account reveals some points relevant to family policy. First, family policy should be de-gendered. Mostly focussing on improving female labour participation and facilitating the reconciliation of family and work for women will not likely be successful in achieving a more egalitarian labour division in households. Rather, policy must at the same time work on improving father's opportunities in taking a more important role at home (Aidukaite \& Telisauskaite- 


\begin{tabular}{|c|c|c|c|c|c|c|c|c|c|c|c|c|c|c|c|c|c|c|}
\hline & & Nesterr & Europ & & & othern & Europ & & Central & Europe & South & ern Ec & urope & Post- & Sociali & ist Cen & tral Eur & ope \\
\hline & BE & IE & NL & UK & DK & $\mathrm{FI}$ & NO & SE & $\mathrm{CH}$ & $\mathrm{DE}$ & ES & GR & PT & $\mathrm{CZ}$ & $\mathrm{EE}$ & $\mathrm{HU}$ & PL & SI \\
\hline & $\mathrm{F} \mathrm{M}$ & $\mathrm{F} \mathrm{M}$ & $\mathrm{F} \mathrm{M}$ & $\mathrm{F} \mathrm{M}$ & $\mathrm{FM}$ & $\mathrm{F} \mathrm{M}$ & $\mathrm{F} \mathrm{M}$ & $\mathrm{F} \mathrm{M}$ & $\mathrm{F} \mathrm{M}$ & $\mathrm{F} \mathrm{M}$ & $\mathrm{F} \mathrm{M}$ & $\mathrm{F} \mathrm{M}$ & $\mathrm{F} \mathrm{M}$ & $\mathrm{F} \mathrm{M}$ & $\mathrm{FM}$ & $\mathrm{FM}$ & $\mathrm{FM}$ & $\mathrm{FM}$ \\
\hline Age & & & & & & & & & & & & & & & & + & & \\
\hline Child & & & & + & & \pm & & & & & & & \pm & & & & & \\
\hline Subjective Income & & & & - & - & & - & & & & & $y$ & & & & $(-)$ & \pm & \\
\hline Education & & $(+)$ & + & + & $(+)$ & & & & $(+)$ & & \pm & & & & & & & \\
\hline Occupation & & & + & + & & & & & & + & & & & + & & & $(-)$ & \\
\hline Fixed-Term Contract & & & & & & & & $(+)$ & $(-)$ & $(+)$ & & & & + & & & & $(+)$ \\
\hline Work Hard & & & & ++ & ++ & $(+)$ & + & $(-)(+)$ & + & ++ & + & & & & $(+)$ & + & + & \\
\hline Time Pressure & ++ & $+(+)$ & $+(+)$ & ++ & ++ & ++ & ++ & $+( \pm)$ & + & ++ & $+( \pm)$ & ++ & $( \pm)$ & ++ & $( \pm)$ & ++ & + & ++ \\
\hline Flexibility & & & & & $( \pm)$ & & & & & $( \pm)$ & & $(-)+$ & & & & & & $(+)$ \\
\hline Work Hours & + & + & $+(+)$ & + & $(+)(+)$ & $+(+)$ & + & ++ & + & $+(+)$ & ++ & & + & + & + & & & \\
\hline Work Hours Partner & & & & - & & $(+)$ & & $(-)$ & & & & & - & $(+)$ & & $(-)$ & $(-)$ & \\
\hline Unsocial Time & ++ & + & ++ & ++ & ++ & ++ & ++ & ++ & $+(+)$ & ++ & ++ & + & $+(+)$ & ++ & ++ & ++ & ++ & ++ \\
\hline Unsocial Time Partner & & & & - & & & & & & $(-)$ & $(-)$ & & & $(+)$ & & & & \\
\hline Cut Household & $(+)$ & & $(+)$ & & & + & + & & & ++ & & $(+)$ & & ++ & + & $(+)$ & $+(+)$ & $(+)$ \\
\hline Crisis Job & & + & & ++ & $+(+)$ & + & + & + & + & + & & + & & $(+)$ & & $+(+)$ & $(+)$ & + \\
\hline
\end{tabular}

Figure 1. Graphical representation of effect size by country group, country and gender.

Cekanavice, 2020; Geszler, 2020; Zimmermann \& LeGoff, 2020) and include models enabling parenting and being successful at work for both genders. Technology can be a facilitator in reconciling work and family demands but can have adverse effects if corporate colonisation is not countered (Nagy, 2020).

Second, families are fragile environments and worklife conflict is very context-dependent. Vulnerability is not only linked to a few conditions such as unemployment or single parenting, but many situations can lead to issues of work-life conflict and thus family problems, such as having multiple jobs, both parents working at unsocial times, trying to live gender equality in a traditional setting or vice versa etc. (Bornatici \& Heers, 2020; Kromydas, 2020; Ochsner \& Szalma, 2017; Ukhova, 2020; Zimmermann \& LeGoff, 2020). Attitudes towards family arrangements do not only vary between countries, but also between regions and social classes (Ukhova, 2020; Zimmermann \& LeGoff, 2020). Also, what can be achieved depends on contexts and it can be more stressful if the own preference is not congruent with the general attitude of the population and thus lead to work-life conflict. Family policy should therefore propose solutions for reconciliations of work and family for several arrangements of labour division within families and couples.

Third, different levels of jobs come with different problems. Having more autonomy on working hours might help reconcile work and family demands but this comes most likely with pressures to be always reachable. Tools to counter work-life conflict might differ between different levels of jobs: While technology might help managers to keep contact with their family, it might rather lead to corporate colonisation, i.e., expanding working time into family time, in so-called sandwich positions where workers take responsibility but do not have full autonomy (see Geszler, 2020; Nagy, 2020). Reconciliation measures should therefore take such different working conditions into account and tools should be available for all positions, also at the highest level, both to increase the female share in such positions and also to enable fathers in such positions to take responsibility in family matters.

Fourth, there is an interaction between policy and economy. Policies can introduce measures to facilitate reconciliation of work and family. However, companies act within those contexts and are aware of policies as they need to be competitive in the country's context. The availability of childcare institutions might facilitate family organisation, but it might also lead to higher expectations of employers towards parents as those parents are able to outsource family work. Also, companies can use reputation of reconciliation practices and advertise them to recruit talent. In practice, however, their approach towards parents might not be much different from average companies as the case of a Swedish company in Hungary suggests (Geszler, 2020). This has not only implications for policy makers who should acknowledge and anticipate such adaptations, but also on practitioners consulting workers and families in their coping strategies. Finally, it is relevant for research on family policy that it should be more aware of such cross-level interaction effects.

Fifth, a reflection regarding the scientific rather than the policy discourse, research comparing countries regarding family policies should take the different norms and policies in the examined countries into account and 
should refrain from assuming general effects of policies across countries. Multilevel modelling should only be used when its assumptions are tenable. Rather, other modelling strategies should be applied, especially models taking country differences of individual level effects into account, such as two-step approaches.

Finally, we want to put forward that major events on the macro level, such as the economic crisis in 2007 or the current COVID-19 pandemic can have a strong impact on labour division within families and couples. It will most likely have some effects into the direction of a more traditional family model, but this might very well differ more strongly between social classes than in so-called normal times (see Ukhova, 2020).

\section{Acknowledgments}

The preparation of this thematic issue by Michael Ochsner and Ivett Szalma was supported by the Academic Publishing Workshop Award (H2020 ESS-SUSTAIN). The contribution of Judit Takács was supported by the Academy in Exile Fellowship at the Kulturwissenschaftliches Institut (KWI) Essen.

\section{Conflict of Interests}

The authors declare no conflict of interests.

\section{Supplementary Material}

Supplementary material for this article is available online in the format provided by the authors (unedited).

\section{References}

Achen, C. H. (2005). Two-step hierarchical estimation: Beyond regression analysis. Political Analysis, 13(04), 447-456. http://doi.org/10.1093/pan/mpi033

Aidukaite, J., \& Telisauskaite-Cekanavice, D. (2020). The father's role in child care: Parental leave policies in Lithuania and Sweden. Social Inclusion, 8(4), 81-91. http://doi.org/10.17645/si.v8i4.2962

Bartha, A., \& Zentai, V. (2020). Long-term care and gender equality: Fuzzy-set ideal types of care regimes in Europe. Social Inclusion, 8(4), 92-102. http://doi.org/ 10.17645/si.v8i4.2956

Beck, U., \& Beck-Gernsheim, E. (2011). Fernliebe. Lebensformen im globalen Zeitalter [Long-distance love. Lifestyles in the global age]. Berlin: Suhrkamp.

Bornatici, C., \& Heers, M. (2020). Work-family arrangement and conflict: Do individual gender role attitudes and national gender culture matter? Social Inclusion, 8(4), 46-60. http://doi.org/10.17645/si.v8i4.2967

Bowers, J., \& Drake, K. W. (2005). EDA for HLM: Visualization when probabilistic inference fails. Political Analysis, 13(4), 301-326. http://doi.org/10.1093/ pan/mpi031

Bryan, M. L., \& Jenkins, S. P. (2016). Multilevel modelling of country effects: A cautionary tale. European Sociological Review, 32(1), 3-22. http://doi.org/10.1093/ esr/jcv059

Crompton, R., \& Lyonette, C. (2006). Work-life 'balance' in Europe. Acta Sociologica, 49, 379-393. https://doi. org/10.1177/0001699306071680

Estéves-Abe, M., \& Hobson, B. (2015). Outsourcing domestic (care) work: The politics, policies, and political economy. Social Politics: International Studies in Gender, State \& Society, 22(2), 133-146. http://doi.org/ 10.1093/sp/jxv011

European Social Survey. (2012). ESS round 5 (Data file edition 3.2) [Data set]. Bergen: Norwegian Centre for Research Data.

Gallie, D., \& Russell, H. (2009). Work-family conflict and working conditions in Western Europe. Social Indicators Research, 93(3), 445-467. http://doi.org/ 10.1007/s11205-008-9435-0

Geszler, N. (2020). Agency and capabilities in managerial positions: Hungarian fathers' use of workplace flexibility. Social Inclusion, 8(4), XX-XX. http://doi.org/ 10.17645/si.v8i4.2969

Hu, Y., \& Yucel, D. (2018). What fairness? Gendered division of housework and family life satisfaction across 30 countries. European Sociological Review, 34(1), 92-105. http://doi.org/10.1093/esr/jcx085

Kingsley, P. (2020, May 30). A mile-long line for free food in Geneva, one of world's richest cities. New York Times. Retrieved from https://www.nytimes. com/2020/05/30/world/europe/genevacoronavirus-reopening.html

Kromydas, T. (2020). Educational attainment and gender differences in work-life balance for couples across Europe: A contextual perspective. Social Inclusion, 8(4), 8-22. http://doi.org/10.17645/si.v8i4.2920

Lutz, H. (2002). At your service madam! The globalization of domestic service. Feminist Review, 70(1), 89-104. http://doi.org/10.1057/palgrave.fr.9400004

Masuda, A. D., Sortheix, F. M., Beham, B., \& Naidoo, L. J. (2019). Cultural value orientations and work-family conflict: The mediating role of work and family demands. Journal of Vocational Behavior, 112, 294-310. http://doi.org/10.1016/j.jvb.2019.04.001

Nagy, B. (2020). "Mummy is in a call": Digital technology and executive women's work-life balance. Social Inclusion, 8(4), 72-80. http://doi.org/10.17645/ si.v8i4.2971

Ochsner, M., \& Szalma, I. (2017). Work-life conflict of working couples before and during the crisis in 18 European countries. In M. J. Breen (Ed.), Values and identities in Europe. Evidence from the European Social Survey (pp. 103-125). Abingdon: Routledge.

OECD. (2011). OECD social indicators: Society at a glance 2011. Paris: OECD Publishing. http://doi.org/ 10.1787/soc_glance-2011-en

Ruppanner, L. (2011). Conflict between work and family: An investigation of four policy measures. Social Indicators Research, 110(1), 327-347. http://doi.org/ 


\subsection{7/s11205-011-9933-3}

Ruppanner, L., Bernhardt, E., \& Brandén, M. (2017). Division of housework and his and her view of housework fairness: A typology of Swedish couples. Demographic Research, 36, 501-524. http://doi.org/ 10.4054/DemRes.2017.36.16

Strandh, M., \& Nordenmark, M. (2006). The interference of paid work with household demands in different social policy contexts: Perceived work-household conflict in Sweden, the UK, the Netherlands, Hungary and the Czech Republic. British Journal of Sociology, $57,597-617$.

Ukhova, D. (2020). Gender division of domestic labor in post-socialist Europe (1994-2012): Test of class gradients hypothesis. Social Inclusion, 8(4), 23-34. http:// doi.org/10.17645/si.v8i4.2972

Zimmermann, R., \& LeGoff, J.-M. (2020). The transition to parenthood in the French and German speaking parts of Switzerland. Social Inclusion, 8(4), 35-45. http://doi.org/10.17645/si.v8i4.3018

\section{About the Authors}
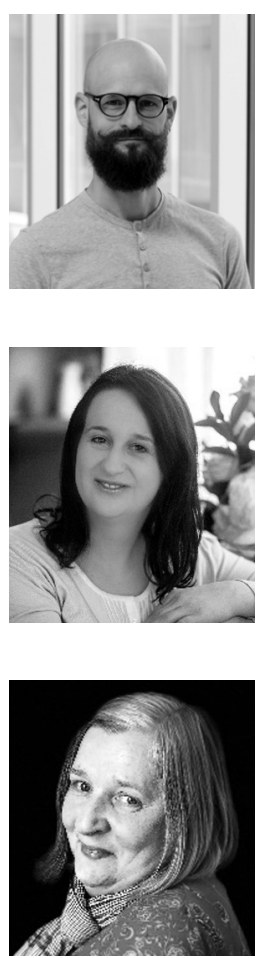

Michael Ochsner is a Senior Researcher at FORS, Swiss Centre of Expertise in the Social Sciences in Lausanne. He is a survey methodologist involved in the implementation of the ESS, the ISSP and the EVS in Switzerland. His research covers welfare policy and legitimacy of the state, work-life conflict, cultural differences in survey research, representation bias and survey modes. He is also a specialist on research quality and evaluation in the social sciences and humanities. Image ( felix imhof

Ivett Szalma is a Postdoctoral Fellow at the Centre for Social Sciences, Hungarian Academy of Sciences Centre of Excellence and an Associate Professor at the Corvinus University of Budapest, and the Head of the Family Sociology Section of the Hungarian Sociological Association. Her research topics include the effects of economic crises on work-life conflicts, post-separation fertility, childlessness, nonresident fatherhood, measurement of homophobia and adoption by same-sex couples.

Judit Takács is a Research Chair at the Centre for Social Sciences, Hungarian Academy of Sciences Centre of Excellence, responsible for leading research teams and conducting independent research on topics including family practices, work-life balance issues, childlessness as well as social history of homosexuality, social exclusion/inclusion of LGBTQ+ people, HIV/AIDS prevention. Currently she is an Academy in Exile fellow at KWI, Essen. 